\title{
Investigations on the Characteristics of Pulse Plating on Printed Circuit Board
}

\author{
S. Jayapoorani \\ Assistant Professor, \\ Department of Electronics \\ and Communication Engineering \\ Sona College of Technology \\ Salem-636005, Tamil Nadu
}

\author{
Dalim Kumar Ghosh \\ Associate Professor, \\ Department of Maths \\ VSB Engineering \\ College \\ Karur, Tamil Nadu
}

\begin{abstract}
A research is carried to evaluate the performance between the pulse plating and pulse reverse plating technique. In both the technique employed the composition of the bath is kept constant.Both the plating is done on a double sided Printed Circuit Board for the connection between the two layers. The metal used for plating is silver rather than the conventional copper. The evaluation of parameters such as hardness and current efficiency is carried out.
\end{abstract}

Keywords: Printed Circuit Board, Pulse plating, Pulse Reverse plating, silver, current efficiency

\section{INTRODUCTION}

Printed Circuit Boards (PCB) are the vital components of any electronic system. They are made of glass fiber with reinforced epoxy resin. Here efforts are taken to optimize the plating characteristics of a double sided Printed Circuit Board. Printed circuit boards have many constraints. This initial research leads into many areas of study in PCB design optimization and analysis. Main constraints of PCB is reduced area, increased component density, mixed signal components[14]. An effort to improve design technology and quality of PCB is carried out. Corrosion of electronic component especially PCB is a significant issue[7]. Copper is the material which is used widely for plating of PCB. Copper is corrosive when exposed to moisture. This characteristic is referred to as patina. When copper becomes corrosive it forms light blue powder.

$4 \mathrm{Cu}+4 \mathrm{OH}-=2 \mathrm{Cu}_{2} \mathrm{O}+2 \mathrm{H}_{2} \mathrm{O}+4 \mathrm{e}^{--------(1)}$

The spacing between the components of PCB is less. Even if there is loss of picograms of the material in the conducting path of PCB it will lead to fault. Fault Tolerance of PCB is very less. The spacing between the components is of the order of 5 microns. Thus great care has to be taken to overcome this problem of corrosion.

\section{RELATED WORK}

Conventional method of plating for PCB is DC plating. Plating forms a very important step for double sided PCB [13].Here pulse plating technique is proposed. It consists of a plating bath and pulse rectifier equipment. In the plating bath, silver is used as anode and PCB board as cathode. Silver is a metal which has $7 \%$ higher conductivity than copper[12]. All metals are polycrystalline and they are built from any crystals.
When pulse plating of silver is done on PCB, it leads to leaving of ions from silver to the PCB board. It leads to the presence of an unoccupied state at anode. It is due to the electron migrating from anode to cathode.

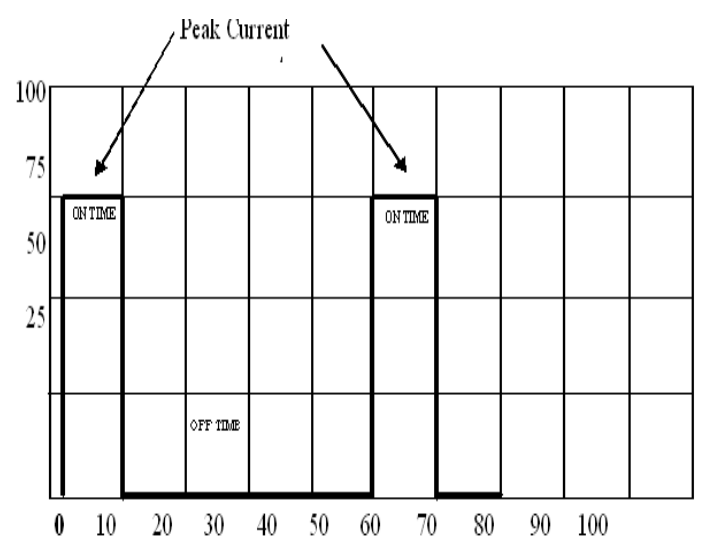

Fig 1 Pulse Current

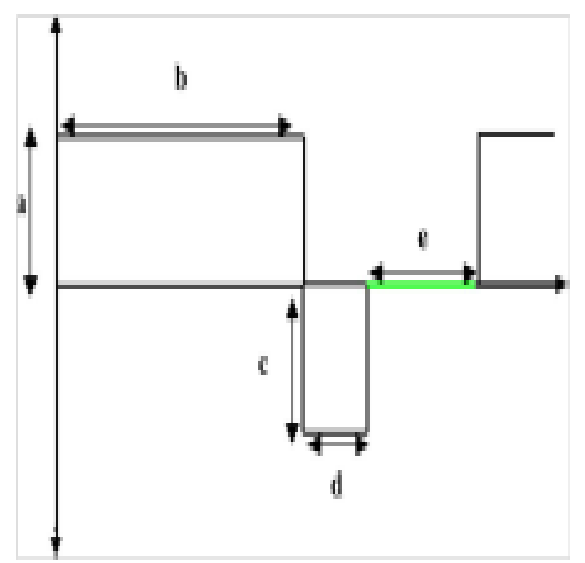

Fig 2 :Pulse reverse current 


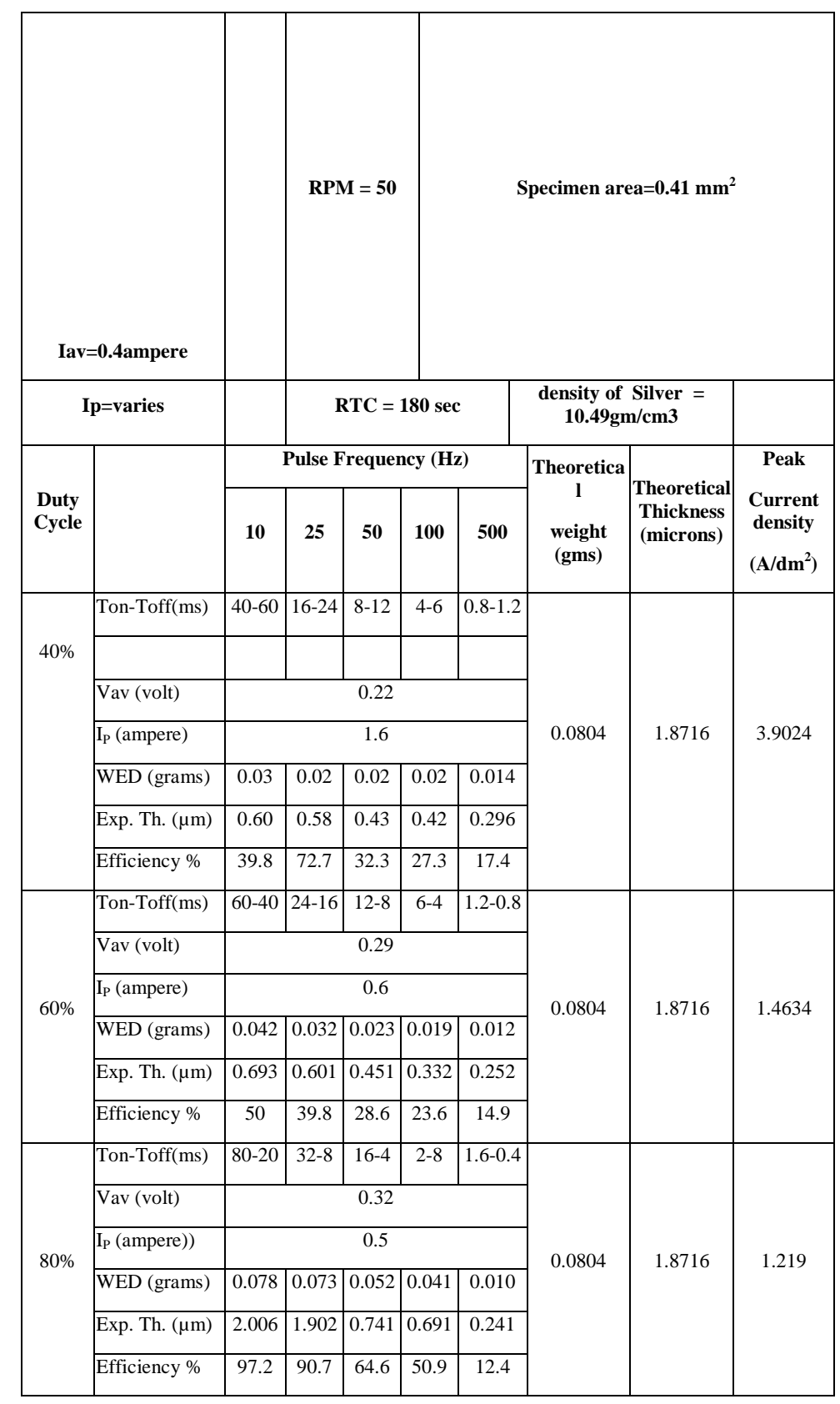

Table 1: Various calculations in pulse reverse plating

\begin{tabular}{|l|l|}
\hline Definition & $\begin{array}{l}\text { Mathematical } \\
\text { expressions }\end{array}$ \\
\hline Frequeny & $\mathrm{f}=1 /(\mathrm{b}+\mathrm{d}+\mathrm{e})$ \\
\hline $\begin{array}{l}\text { Average } \\
\text { current } \\
\text { intensity }\end{array}$ & $\mathrm{I}_{\mathrm{d}}=\left(\mathrm{a}^{*} \mathrm{~b}+\mathrm{c} * \mathrm{~d}\right) /(\mathrm{b}+\mathrm{d}+\mathrm{e})$ \\
\hline $\begin{array}{l}\text { Current } \\
\text { ratio }\end{array}$ & $\mathrm{R}=\mathrm{c} / \mathrm{a}$ \\
\hline Off time & $\mathrm{T}_{\text {off }}=\mathrm{e}$ \\
\hline $\begin{array}{l}\text { Positive } \\
\text { duty cycle }\end{array}$ & $\zeta^{+}=\mathrm{b} /(\mathrm{b}+\mathrm{d}+\mathrm{e})$ \\
\hline $\begin{array}{l}\text { Negative } \\
\text { duty cycle }\end{array}$ & $\zeta^{-}=\mathrm{d} /(\mathrm{b}+\mathrm{d}+\mathrm{e})$ \\
\hline $\begin{array}{l}\text { On duty } \\
\text { cycle }\end{array}$ & $\zeta^{\text {on }=(\mathrm{b}+\mathrm{d}) /(\mathrm{b}+\mathrm{d}+\mathrm{e})}$ \\
\hline
\end{tabular}

In the above fig1, duty cycle is a very important parameter[1].It contains two parameters. They are ON and OFF time. Duty cycle is given by ON time divided by total time(ON time + OFF time)[4]. In order to attain extensive duty cycle range square pulses are used [11] .

Fig 2 refers to Pulse reverse current waveform with the five parameters highlighted

(a) cathodic current intensity amplitude,

(b) cathodic pulse duration on time,

(c) anodic current intensity amplitude,

(d) anodic pulse duration on time, and

(e) off-time of the pulse

There are 3 possible periods.

1 Forward $\mathrm{ON}+\mathrm{OFF}$

\section{Reverse $\mathrm{ON}+\mathrm{OFF}$}

3 Forward+Reverse

The most important part of calculation is that at any time in the opposite direction is same as OFF Time to the direction being calculated and that all of the ON time must be considered for the direction being calculated and not the $\mathrm{ON}$ time of one $\mathrm{ON}+\mathrm{OFF}$ period [13].

When the first pulse is used the concentration of the silver ion falls, its value increases during the off-time during the second pulse the process repeats. The movement of silver ions in bath is due to the hydrogen evolution and also due to the raise of $\mathrm{Ph}$ value at the surface [8].It is also observed that metal deposition is not dependent on pulse lengths.

Table2.

From Table 2 The Experimental Data Obtained for Various Pulse Duty Cycles of $20 \%$ to $80 \%$, at Frequencies $10 \mathrm{~Hz}, 25$ $\mathrm{Hz}, 50 \mathrm{~Hz}, 100 \mathrm{~Hz}$ and $500 \mathrm{~Hz}$ with a Constant Average Current Density0.975amps $/ \mathrm{dm}^{2}$, where Iav $=0.4$ amps (Iav $=$ average current, RPM $=$ Rotation per minute, $\mathrm{I}_{\mathrm{p}}=$ peak current, $\mathrm{RTC}=$ Real time cycle, Ton-ON Time, Ton-OFF Time, WED = Weight Electrodeposited, Exp.Th.-Experimental Thickness) The above values are obtained from pulse plating 
set up.It is observed that with higher duty cycle higher efficiency is obtained.As the duty cycle increases the grain size decreases.

Table 3: Tabulation for Pulse Reverse plating The Various Experimental Data Given to the Rectifier for Pulse

Reverse Plating of Double Sided Printed Circuit Board

\begin{tabular}{|c|c|c|c|c|c|c|}
\hline $\begin{array}{c}\text { Do } \\
\text { E }\end{array}$ & $\begin{array}{c}\text { Revers } \\
\text { e } \\
\text { duratio } \\
\mathbf{n} \\
(\mathrm{ms})\end{array}$ & $\begin{array}{c}\text { Revers } \\
\text { e } \\
\text { ON } \\
\text { time(m } \\
\text { s) }\end{array}$ & $\begin{array}{c}\text { Revers } \\
\text { e OFF } \\
\text { time } \\
(\mathrm{ms})\end{array}$ & $\begin{array}{c}\text { Forwar } \\
\text { d } \\
\text { duratio } \\
\text { n time } \\
\text { (ms) }\end{array}$ & $\begin{array}{c}\text { Forwar } \\
\text { d ON } \\
\text { time } \\
\text { (ms) }\end{array}$ & $\begin{array}{c}\text { Forwar } \\
\text { d } \\
\text { OFF } \\
\text { Time } \\
\text { (ms) }\end{array}$ \\
\hline 1 & -20 & 15 & 5 & 30 & 20 & 10 \\
\hline 2 & -30 & 20 & 10 & 20 & 15 & 5 \\
\hline 3 & -20 & 5 & 15 & 30 & 20 & 10 \\
\hline 4 & -20 & 5 & 15 & 30 & 10 & 20 \\
\hline 5 & -30 & 25 & 5 & 40 & 30 & 10 \\
\hline 6 & -40 & 30 & 10 & 30 & 25 & 5 \\
\hline 7 & -30 & 5 & 25 & 40 & 10 & 30 \\
\hline 8 & -30 & 5 & 25 & 40 & 30 & 10 \\
\hline 9 & -40 & 30 & 10 & 30 & 20 & 10 \\
\hline 10 & -40 & 30 & 10 & 20 & 30 & 10 \\
\hline 11 & -40 & 20 & 20 & 30 & 15 & 5 \\
\hline 12 & -40 & 15 & 5 & 30 & 5 & 15 \\
\hline 13 & -40 & 10 & 30 & 20 & 15 & 5 \\
\hline 14 & -40 & 10 & 30 & 20 & 5 & 15 \\
\hline 15 & -30 & 10 & 20 & 20 & 15 & 5 \\
\hline 16 & -20 & 10 & 10 & 30 & 15 & 5 \\
\hline 17 & -50 & 40 & 10 & 40 & 30 & 10 \\
\hline 18 & -40 & 30 & 10 & 50 & 40 & 10 \\
\hline 19 & -50 & 10 & 40 & 40 & 30 & 10 \\
\hline 20 & -50 & 10 & 10 & 40 & 10 & 20 \\
\hline 21 & -50 & 20 & 30 & 40 & 30 & 10 \\
\hline 22 & -50 & 30 & 20 & 40 & 20 & 10 \\
\hline
\end{tabular}


Ireverse $=1 \mathrm{amps}$ and Vreverse $=10$ volts,$(\mathrm{DoE}=$ Design of Experiment)

Table 3 shows the various experimental data given to the pulse reverse plating setup. The values are designed in such a way that it yields high current efficiency and hardness to the plated printed circuit board. The difference between pulse plating and pulse reverse plating is that with pulse plating there will be only one $\mathrm{ON}+\mathrm{OFF}$ cycle but in reverse pulse plating technique there will be several ON + OFF cycles. If the ON time is in opposite direction then it is equal to OFF time. While calculating not only one ON time is taken for calculation but all $\mathrm{ON}$ time of the whole period is taken for calculation .From Table 3 it is observed that No forward ON time is in negative direction

Table 4 The Experimental Data Obtained for Various Pulse DutyCycles of $10 \%$ to $100 \%$

Ireverse $=1 \mathrm{amps}$ and Vreverse $=10$ volts,$(\mathrm{DoE}=$ Design of Experiment)
From Table 4 for the DOE the respective fDC and efDC is calculated. The fDC is the duty cycle of the settings during the forward time of the waveform. The efDC is the duty cycle of the forward time relative to the overall waveform .rDC is the reverse duty cycle of the settings during the reverse time of the waveform. erDC is the effective duty cycle of the reverse time relative to the overallwaveform. Since there are continuous forward and reverse pulses in Pulse reverse plating technique, it will lead to coarse deposits at the first cycle ,then the reverse current will dissolve the excess of silver deposited, the following forward cycle will plate the silver without any dog boned deposits. Thus reverse cycle leads to better efficiency when compared to pulse plating . But there is a disadvantage that the RTC (Real Time Cycle) maintained is at higher rate when pulse reverse plating is carried

\begin{tabular}{|c|c|c|c|c|c|}
\hline DoE & $\begin{array}{c}\begin{array}{c}\text { Forward } \\
\text { duty Cycle }\end{array} \\
\text { (fDC) in } \\
\%\end{array}$ & $\begin{array}{c}\text { Effective } \\
\text { forward } \\
\text { duty cycle } \\
\text { (efDC) in } \\
\%\end{array}$ & $\begin{array}{c}\text { Reverse duty } \\
\text { cycle (rDC) in } \\
\%\end{array}$ & $\begin{array}{l}\text { Effective } \\
\text { reverse duty } \\
\text { cycle (erDC) } \\
\text { in \% }\end{array}$ & $\begin{array}{l}\text { Effective } \\
\text { Plating } \\
\text { Current }\end{array}$ \\
\hline 1 & 66.7 & 40 & 75 & 30 & $\begin{array}{l}-0.3 \\
\end{array}$ \\
\hline 2 & 75 & 30 & 66 & 40 & -0.4 \\
\hline 3 & 66.7 & 40 & 25 & 10 & -0.1 \\
\hline 4 & 66.7 & 40 & 25 & 10 & -0.1 \\
\hline 5 & 75 & 50 & 100 & 33.3 & -0.3 \\
\hline 6 & 83.3 & 35.7 & 75 & 42.9 & -0.4 \\
\hline 7 & 25 & 14.3 & 16.7 & 7.1 & -0.1 \\
\hline 8 & 75 & 42.9 & 16.7 & 7.1 & -0.1 \\
\hline 9 & 66.7 & 28.6 & 75 & 42.9 & -0.4 \\
\hline 10 & 100 & 33.3 & 75 & 50 & -0.5 \\
\hline 11 & 83.3 & 35.7 & 50 & 28.6 & $\begin{array}{c}-0.3 \\
\end{array}$ \\
\hline 12 & 33.3 & 14.3 & 75 & 42.9 & -0.4 \\
\hline 13 & 75 & 25 & 25 & 16.7 & -0.2 \\
\hline 14 & 25 & 8.3 & 25 & 16.7 & -0.2 \\
\hline 15 & 75 & 30 & 33.3 & 20 & -0.2 \\
\hline 16 & 83.3 & 50 & 50 & 20 & -0.2 \\
\hline 17 & 75 & 33.3 & 80 & 44.4 & -0.4 \\
\hline 18 & 80 & 44.4 & 75 & 33.3 & $\begin{array}{l}-0.3 \\
\end{array}$ \\
\hline 19 & 75 & 33.3 & 20 & 11.1 & -0.1 \\
\hline 20 & 50 & 22.2 & 60 & 33.3 & -0.3 \\
\hline 21 & 75 & 33.3 & 40 & 22.2 & -0.2 \\
\hline 22 & 75 & 33.3 & 60 & 33.3 & -0.3 \\
\hline
\end{tabular}


Table 5 The Experimental Values Namely Frequency, Average Current Intensity, Positive Duty Cycle, Negative Duty Cycle and ON Duty Cycle RTC $=600 \mathrm{sec}$

\begin{tabular}{|c|c|c|c|c|c|c|}
\hline $\begin{array}{l}\text { Do } \\
\text { E }\end{array}$ & $\begin{array}{l}\text { Freq } \\
\text { uenc } \\
\text { y } \\
\text { (Her } \\
\text { tz) }\end{array}$ & $\begin{array}{l}\text { Averag } \\
\text { e } \\
\text { current } \\
\text { intensit } \\
\text { y (mA) }\end{array}$ & $\begin{array}{l}\text { Curren } \\
\text { t Ratio }\end{array}$ & $\begin{array}{l}\text { Positiv } \\
\text { e duty } \\
\text { cycle } \\
(\%)\end{array}$ & $\begin{array}{l}\text { Negati } \\
\text { ve duty } \\
\text { cycle } \\
(\%)\end{array}$ & $\begin{array}{l}\text { On } \\
\text { duty } \\
\text { cycle } \\
(\%)\end{array}$ \\
\hline 1 & 25 & 22.5 & 0.667 & 40 & 37.5 & 87.5 \\
\hline 2 & 22 & 20 & 1.5 & 33 & 44.4 & 77.7 \\
\hline 3 & 25 & 17.5 & 0.667 & 50 & 12.5 & 62.5 \\
\hline 4 & 33 & 13.3 & 0.667 & 33 & 16.6 & 50 \\
\hline 5 & 16.6 & 32.5 & 0.75 & 50 & 41.6 & 91.7 \\
\hline 6 & 15.4 & 30 & 1.33 & 38.5 & 46.2 & 84.6 \\
\hline 7 & 25 & 13.75 & 0.75 & 25 & 12.5 & 37.5 \\
\hline 8 & 16 & 22.5 & 0.75 & 50 & 8.3 & $\begin{array}{c}58.3 \\
3\end{array}$ \\
\hline 9 & 16 & 30 & 1.33 & 33 & 50 & 83.3 \\
\hline 10 & 14.3 & 25.7 & 2 & 43 & 42.8 & 85.7 \\
\hline 11 & 18.2 & 22.7 & 1.33 & 27.3 & 36.36 & 63.6 \\
\hline 12 & 40 & 30 & 1.33 & 20 & 60 & 80 \\
\hline 13 & 18.2 & 12.7 & 2 & 27.3 & 18.2 & 27.3 \\
\hline 14 & 22 & 11.1 & 2 & 11.1 & 22.2 & 33.3 \\
\hline 15 & 22 & 13.3 & 1.5 & 33.3 & 22.2 & 55.5 \\
\hline 16 & 28.6 & 18.57 & 0.667 & 42.8 & 28.6 & 71.4 \\
\hline 17 & 12.5 & 40 & 1.25 & 37.5 & 50 & 87.5 \\
\hline 18 & 12.5 & 40 & 0.8 & 50 & 37.5 & 87.5 \\
\hline 19 & 12.5 & 21.25 & 1.25 & 37.5 & 12.5 & 50 \\
\hline 20 & 33 & 30 & 1.25 & 33.3 & 33 & 66.7 \\
\hline 21 & 12.5 & 27.5 & 1.25 & 37.5 & 25 & 66.7 \\
\hline 22 & 14.3 & 32.85 & 1.25 & 28.6 & 42.9 & 71.4 \\
\hline
\end{tabular}

Table 6 The Experimental Data Obtained after Pulse Reverse Plating Namely Current Efficiency and Hardness

\begin{tabular}{|c|c|c|c|c|c|c|}
\hline DoE & $\begin{array}{c}\text { Average } \\
\text { current } \\
\text { intensity } \\
(\mathbf{m A})\end{array}$ & $\begin{array}{c}\text { Average } \\
\text { current } \\
\text { Density } \\
\mathbf{m A} \\
\mathbf{m m}^{2}\end{array}$ & $\begin{array}{c}\text { Theoretical } \\
\text { weight } \\
\text { (grams) }\end{array}$ & $\begin{array}{c}\text { Experimental } \\
\text { Weight } \\
\text { (grams) }\end{array}$ & $\begin{array}{c}\text { Current } \\
\text { efficiency } \\
(\%)\end{array}$ & $\begin{array}{c}\text { Hardness } \\
\text { (VHN) }\end{array}$ \\
\hline 1 & 22.5 & 54.87805 & 0.0150 & 0.0146 & 97.2 & 76.4 \\
\hline 2 & 20 & 48.78049 & 0.0134 & 0.0123 & 92.3 & 73.2 \\
\hline 3 & 17.5 & 42.68293 & 0.0117 & 0.0103 & 88.4 & 76.2 \\
\hline 4 & 13.3 & 32.43902 & 0.0089 & 0.0050 & 56.2 & 82.2 \\
\hline 5 & 32.5 & 79.26829 & 0.0218 & 0.01813 & 83.2 & 70.4 \\
\hline 6 & 30 & 73.17073 & 0.0201 & 0.0162 & 80.6 & 68.2 \\
\hline
\end{tabular}

\begin{tabular}{|c|c|c|c|c|c|c|}
\hline 7 & 13.75 & 33.53659 & 0.0092 & 0.00547 & 59.4 & 76.1 \\
\hline 8 & 22.5 & 54.87805 & 0.0150 & 0.0146 & 97.2 & 70.8 \\
\hline 9 & 30 & 73.17073 & 0.0201 & 0.0162 & 80.7 & 68.1 \\
\hline 10 & 25.7 & 62.68293 & 0.0172 & 0.01625 & 94.3 & 68.1 \\
\hline 11 & 22.7 & 55.36585 & 0.0152 & 0.01496 & 98.3 & 71.2 \\
\hline 12 & 30 & 73.17073 & 0.0201 & 0.0162 & 80.6 & 87.3 \\
\hline 13 & 12.7 & 30.97561 & 0.0085 & 0.00402 & 47.3 & 70.1 \\
\hline 14 & 11.1 & 27.07317 & 0.00744 & Poor deposit & & \\
\hline 15 & 13.3 & 32.43902 & 0.00892 & 0.00501 & 56.2 & 73.1 \\
\hline 16 & 18.57 & 45.29268 & 0.01245 & 0.01128 & 90.6 & 78.2 \\
\hline 17 & 40 & 97.56098 & 0.02683 & Burnt deposit & & \\
\hline 18 & 40 & 97.56098 & 0.02683 & Burnt deposit & & \\
\hline 19 & 21.25 & 51.82927 & 0.01425 & 0.01347 & 94.5 & 65.3 \\
\hline 20 & 30 & 73.17073 & 0.02012 & 0.0162 & 80.7 & 82.2 \\
\hline 21 & 27.5 & 67.07317 & 0.01844 & 0.01663 & 90.2 & 65.3 \\
\hline 22 & 32.85 & 80.12195 & 0.02203 & 0.01833 & 83.2 & 66.3 \\
\hline
\end{tabular}

\section{RESULTS AND DISCUSSION}

From the tabulations obtained for various average current density it is observed that the highest current efficiency is found for constant average current density 55.36585 .DOE 11 has Reverse duration as 40seconds, Reverse ON time as 20seconds reverse OFF time as 20 seconds, Forward duration time as 30 seconds ,Forward ON time as 15 seconds and Forward OFF time as 5 seconds. The maximum current efficiency obtained is 98.3.The maximum hardness obtained is at DOE12 and its value is 87.3 but its current efficiency is 80.3. So DOE11 is considered as optimal fo plating .

\section{CONCLUSION}

Silver on pulse plating for double sided PCB with necessary thickness inside hole provides long lasting and reliable corrosion preventive agent.The area where this silver plating does not work effectively and form corrosion is when it is exposed to the atmosphere of hydrogen sulphide[10]. Otherwise, silver that too with pulse plating is the best form for double sided printed circuit boards particularly.Here, silver is used for plating instead of the conventional copper.When copper is used it leads to corrosion, whereas silver is highly corrosion resistant. Corrosion can impair the wire's fatigue life and electrical conductivity.

Reasons for choosing silver instead of conventional copper are Exceptional Electrical Conductivity nearly $7 \%$ higher conductivity than copper.It has a good resistance to high temperature.Suitable for RF applications .Solder ability and crimpability is high. Use of Silver leads to better hardness and current efficiency. It is reliable for space craft applications

\section{ACKNOWLEDGEMENTS}

The authors gratefully acknowledge the Nanomaterials and micromachining laboratory present at Sona college of Technology for pulse plating and PSG College of Technology for the SEM details. We Thank R.M Arunachalam for rendering help in plating technology. 


\section{REFERENCES}

[1] K.C. Yung, T.M Yue, K.C. Chan and K.F. Yeung (2004) "The effect of waveform for pulse plating on copper plating distribution of microvia in PCB Manufacture" Int.J Adv Manuf Technol(2004) 23:245- 248

[2] Beica, R., C. Sharbono, and T. Ritzdorf.."Through silicon via copper electrodeposition for 3D integration". Proc 58Th Electronic Components \& Technology Conference.2008, pp.577-583.

[3] W.kim and R.weil, "Pulse plating effects in nickel electro deposition", Surface Coating Technology1989,vol .38,pp 289.

[4] M.S. Chandrasekar, Malathy Pushpavanam, "Pulse and pulse reverse plating-Conceptual,advantages and applications", Electrochimica Acta 53 (2008)pp 3313-3322

[5] B.D. Dunn, A. de Rooij \& D.S. Collins, "Corrosion of Silver-Plated Copper Conductors", ESA Journal 1984, Vol. 8 pp 307-335

[6] Nassar Kanani, "Eletroplating Basic Principles, processes and Practice",pp ISBN-10: 1-85617-451-4,

[7] P. T. Tang, P. Leisner, and P. Møller, AESF SurFin '93 _American Electroplaters and Surface Finishers Society, Orlando, FL, 1993, p. 249-256.

[8] B. N. Popov, Ken-Ming Yin and R. E. White “' Galvanostatic Pulse and Pulse Reverse Plating of NickelIron Alloys from Electrolytes Containing, Organic Compounds on a Rotating Disk Electrode" Journal of Electrochemical society vol 140, No 5, 1993.

[9] D.L. Grimmett, M. Schwartz, K. Nobe, The Electrochem. Soc. Inc. 140 (1993) 973

[10] Bella H. Chudnovsky “ Degradation of Power Contacts in Industrial Atmosphere:Plating Alternative for Silver and Tin” IEEE 2003 pp 98-106
[11] S.Jayapoorani, Dalim Kumar Ghosh, AzadMohammed Shaik "A Novel Technique to Perform Plating on Printed Circuit Board" American journal of applied sciences, Vol 8,2011 pp 989-991

[12] S.Jayapoorani,Dalim Kumar Ghosh "Effect of Pulse plating using Silver on Printed Circuit Boards" International journal of Communication, computation and Innovation ,Vol 2 Issue $2,2011 \mathrm{pp} 143-147$

[13] S.Jayapoorani,Dalim Kumar Ghosh "Effect of Pulse Reverse plating using silver on Printed circuit Board" International Journal of Computer applications ,Issue 10,2012

[14] Bosshart, W.C.,(2008). Printed Circuit Boards Design and Technology. Tata Mc Graw Hill publishing Company. 270290 ISBN 0-07-451549-7.

\section{AUTHOR'S PROFILE}

S.Jayapoorani currently pursuing $\mathrm{Ph}$.D Degree in Electronics and Communication Engineering, received M.E degree from K.S.R. College of Technology, Tiruchengode, TamilNadu in the year 2005, B.E in Electronics and Communication Engineering in 2001.In 2005 she joined as a lecturer in SNS college of Technology, Coimbatore Tamilnadu. Currently with Sona College of Technology, Salem as Assistant Professor of Electronics and Communication Engineering, her research interests include Nanometer(ms)ials, Printed circuit boards, plating, and characterization. She has contributed 6 technical papers in various conferences.

Dalim Kumar Ghosh Received his Ph.D degree from IIT Kharagpur,completed his post graduation and under graduation also from the same university. Currently with VSB Engg. College as Associate Professor has a total 11 years Experience in teaching. He is involved in research activities. His area of interest is Theory of Computation. He has published many papers in International journals based on compiler Design. 